\title{
Meningkatkan Kreativitas Anak Melalui Media Pembelajaran Bermain Di Kelompok Bermain Damar
}

\section{Oleh Sugiharto ${ }^{1}$}

\begin{abstract}
Abstrak: Media pembelajaran mempunyai peranan penting dalam kegiatan pembelajaran karena dengan menggunakan media pembelajaran, maka kegiatan menjadi lebih efektif. Penggunaan media pembelajaran disesuaikan dengan tujuan dan sasaran yang hendak dicapai. Jika tujuan pembelajaran untuk meningkatkan kreativitas anak maka terdapat berbagai pilihan media yang digunakan, salah satunya adalah media pembelajaran bermain.
\end{abstract}

Kata-kata Kunci: Kreativitas Anak, Media Pembelajaran Bermain, Kelompok Bermain

\section{A. Pendahuluan}

Pengembangan pendidikan anak usia dini (PAUD) merupakan upaya pembinaan dan pengembangan yang ditujukan bagi anak usia 0-6 tahun. Dalam aspek-aspek kesehatan gizi, psikososial (kognitif, sosial,emosional) yang dilakukan oleh lingkungan masyarakat, kelompok belajar, dan lingkungan keluarga.

Pendidikan tersebut mempunyai pengaruh besar terhadap proses pertumbuhan dan perkembangan ana, sebab menurut pakar neorologi berpendapat bahwa ketika anak berumur 0-4 tahun pertumbuhan kecerdasan otaknya berkembangan dengan pesat, yaitu 4 tahun pertama jaringan sel otak yang disebuta synab berkembang menjadi synapsis-synapsis mencapai 50\%, setgelah 4 tahun kemudian yaitu ketika anak berusia 8 tahun pertumbuhan synap yang menjadi synapsis mencapai $80 \%$ dan ketika anak mencapai usia 18 tahun barulah synapsis menjadi $100 \%$.

Pendidikan anak usia dini dilaksanakan melalui 3 jalur, pendidikan formal yang berbentuk Taman Kanak-Kanak, Raudlatul adfal atau bentuk lain yang sederajat, untuk jalur non formal dilaksanakan melalui Kelompok Bermain, Taman Penitipan Anak dan Satuan Pendidikan Sejenis. Satuan Pendidikan Sejenis dapat berupa Pendidikan Anak Usia Dini yang diintegrasikan dnegan Posyandu yang disebut Pos PAUD, diintegrasikan

\footnotetext{
${ }^{1}$ Sugiarto adalah Pamong Belajar UPLKB Dinas Pendidikan Propinsi Kal-Bar
} 
dengan Taman Baca Al Quran dinamakan anak shaleh, diintegrasikan dengan agama Hindu Budha dinamakan Bina Iman dan diintegrasikan dnegan agama Kristen Protestan dinamakan Sekolah Minggu. Sedangkan yang dilakukan melalui pendidikan informal adalah pendidikan yang dilaksanakan oleh lingkungan keluarga, pendidikan tersebut dimaksudkan untuk membantu mengembangkan pertumbuhan dan perkembangan bagi anak usia dini.

Seiring dengan kemajuan jaman dewasa ini, kesibukan orang tua semakin meningkat sehingga keluarga kadang-kadang kurang memperhatikan terhadap perumbuhan dan prkembangan anaknya. Keluarga sibuk bekerja menjalankan tugas rutinitas sehari-hari efeknya mengikut sertakan anaknya pada satuan Paud yang diselenggarakan oleh masyarakat dengan kondisi, bentuk, tata cara dan aturan yang berbeda. Hal ini di sebabkan oleh situasi dan kondisi lingkungan serta kemampuan social ekonomi masyarakat yang beraneka ragam.

Usia $0-5$ tahun merupakan usia emas, pada masa tersebut sangat rawan apabila orang tua salah memberikan rangsangan dan stimulant maka berakibat pada masa dewasa nantinya. Upaya pengembangan dan pemberian rangsangan tersebut dilakukan melalui kegiatan bermain atau belajar sambil bermain.

Oleh karena itu untuk menunjang kegiatan bermain dan belajar diperlukan suatu media dalam bentuk alat peraga yg menarik sesuai dgn karakteristik perkembangan anak. Proses pembelajaran yg menyenangkan apabila didukung oleh media dalam bentuk alat peraga yg menyenangkan pula.

Media dalam bentuk alat peraga kurang diperhatikan oleh pendidik bahkan dalam bermain dengan tema dan indikator tertentu pendidik tidak menggunakan media dalam bentuk alat peraga sama sekali.

Hal ini karena kurangnya kreatifitas, keterampilan yang dimiliki oleh pendidik indikator lain kekuragan danapengembangan mdia pembelajaran, sehingga terjadi monolitas dalam bermain serta hasil yang dicapai kurang sesuai dengan harapan. Media dalam bentuk alat peraga memegang peranan penting dalam mendukung berhasil tidaknya proses bermain yang efektif dan efisien. Pendidik dituntut mengembangkan model-model pembelajaran yg dapat membangkitkan dan memotivasi peserta untuk belajar dengan aktif, kreatif dan menantang,

Modul ini sedikit membuka peningkatan kreatifitas melalui media pembelajaran diawali dengan latar belakang, membahas tentang apa yang dimaksud dengan kreatifitas dan media pembelajaran, dilanjutkan dengan mengapa perlu adanya kreatifitas dan media pembelajaran yang dikaitkan dengan beberapa kesalahan penidik, bagaimana seharusnya anak bermain, 
dimana dilaksanakan, kapan waktunyuasemua akan dibahas dengan sederhana.

\section{B. Kreatifitas Anak dan Media Pembelajaran Bermain}

\section{Pengertian Kreativitas}

Kreatif, adalah suatu kegiatan yang menggunakan apa saja menjadi media bermain. Contohnya kotak-kotak bekas yang mempunyai bentuk kubus, segitiga, segi empat, dan lain-lain, sebagai dasar untuk pengenalan bentuk, bahan alam yang ada disekitar anak seperti halnya pasir untuk engenalan bentuk dan melatih motorik halus. Suara binatang dapat juga digunakan untuk pengenalan jenis binatang disekitar kita, pendidik menggunakan suaranya untuk menirukan suara-suara binatang, contohnya binatang peliharaan kucing, pendidik/pengasuh dapat menirukan suara kucing yaitu "me...yong...,me...yong...".sambil bernyaanyi, menari, berjalan melingkar menirukan cara bergerak kucing, dan bagi peserta yang belum pernah melihat kucing memiliki wawasan sedikit tentang kucing.

Permainan edukatif kreatif adalah permainan yang dirancang untuk kepentingan pendidikan, dan mempunyai beberapa ciri, agar dapat dengan mudah dipergunakan untuk mencapai tujuan, manfaat dan bermacam-macam bentuk dan modelnya.

Permainan edukatif kreatif dapat bersumber dari lingkungan alam sekitar peserta didik, karena lingkungan merupakan media yang sangat tepat untuk dijadikan bahan pembelajaran bagi anak. Permainan tersebut berupa bahanmentah atau benda yang sudah siap pakai digunakan menjadi media permainan edukatif, maupun yang harus dibuat baru atau dimodifikasi /dilengkapi.

Permainan edukatif kreatif berfungsi sebagai sumber pengetahuan, keterampilan yang baru bagi anak, sekaligus sebagai medium pengembangan nalar dan kreatifitas anak, seperti berfikir, menganalisa, memecahkan masalah sendiri, serta berbuat secara sistematik dan logik.

\section{Pengertian Media Pembelajaran}

Terdapat beberapa pengertian media pembelajaran yang dikemukakan oleh para ahli da;am bidangnya. Miarso, Y. ( $1984: 48$ ) mengemukan bahwa media pembelajaran adalah segala sesuatu yang dapat digunakan untuk merangsang pikiran, perasaan, perhatian dan kemauan siswa sehingga dapat mendorong terjadinya proses belajar pada diri siswa. Hal yang sama dikemukakan juga oleh Djahiri (1992: 1) bahwa media pembelajaran adalah ahli wujud daripada bahan ajar dan atau target hasil dan proses belajar mengajar yang dapat digunakan untuk menyalurkan pesan, 
merangsang pikiran, perasaan, perhatian, dan kemauan siswa sehinga dapat mendorong proses belajar. Sedangkan Sudjana ( 1991: 2 ) menyatakan bahwa media pengajaran dapat mempertinggi proses belajar siswa dalam pengajaran yang pada gilirannya diharapkan dapat mempertinggi proses belajar siswa.

Media pembelajaran adalah suatu benda atau alat yang digunakan oleh pendidik untuk memperjelas dan mempermudah dalam proses kegiatan pembelajan bagi peserta didik. Media pembelajaran yg dimaksud dalam tulisan ini adalah alat peraga dari linkungan belajar sebagai media pembelajaran yg dapat membantu pendidik dalam memotifasi, mengekslorasi semua yang ada ada pikiran anak.

Bermain anak dapat dilaksanakan melalui beberapa jenis area seperti area bahasa, koknitif, seni sosial emosional, psikomotor dan lainya. Jenis media diantaranya media audio, media visual dan media audio visual.

\section{Pentingnya kreativitas dan media pembelajaran}

Pendahuluan modul telah dijelaskan kaitanya dengan proses kegiatan pendidik, ada sebagian pendidik yang apabila melaksanakan kegiatan pembelajaran kurang memperhatikan langkah-langkah yang harus dipersiapkan dalam roses pembelajaran, pendidik juga mengalami kesalahan pada waktu menjalankan tugasnya diantaranya:

a. Mengambil Jalan Pintas dalam Pembelajaran

- mengangap/merasa dirinya sudah berpengalaman atau mengajar dengan dengan baik, sehingga merasa tidak perlu membuat persiapan pembelajaran

- Kurang memahami model pembelajaran yang efektif dan efisien, sehingga pendidik kurang memperhatikan perbandingan jumlah alatbermain dengan jumlah anak-anak serta intensitas bermain anak, dalam hal ini bermain harus dierhitungkan.

b. Menunggu Peserta Didik Berperilaku Negatif

- setiap anak senang memperoleh perhatian dan pujian, namun hal ini jarang dilakukan oleh pendidik

- jika pendidik kurang memberikan perhatian kepada anak, maka anak tidak jarang berprilaku kurang baik. Mereka berlaku kurang baik, semata-mata untuk memperoleh perhatian pendidikanya

- dan pendidik baru memberikan perhatian setelah anak melakukan hal-hal atau berperilaku negatif 
c. Menggunakan Descructive Dicipline

- Jika anak berbuat kekeliruan,tidak benar, atau melanggar tata tertib/disiplin, tetapi pendidik tidak memiliki rencana tindakan yang benar untuk mengatasinya.

- pendidik memberikan tugas kepada anak, tetapi dia tidak pernah memberikan umpan balik terhadap tugas-tugas yang dikerjakan oleh anak

d. Mengabaikan perbedaan anak (peserta didik) padahal setiap anak memiliki perbedaan yang unik baik:

- $\quad$ kekuatan, kelemahan, minat \& perhatian yang berbeda

- latar belakang keluarga,sosial ekonomi \& lingkungan membuat peserta didik berbeda dalam aktifitas, kreatifitas, intelegensi dan kompetensinya

- setiap peserta didik juga memiliki emosi yang sangat bervariasi, dan sering memperlihatkan perilaku yang tidak sama satu sama lain

e. Merasa Paling Pandai

- Sering menganggap peesrta didik tidak tau apa-apa, dia dipandang sebagai gelas yang perlu diisi air kedalamnya.

f. Berlaku tidak adil (diskriminatif)

- pendidik yang tidak adil atau bertindak diskrimintatif kepada anak dapat merugikan perkembangan peserta didik, padahal pembelajaran yang baik dan efektif adalah yang mampu memberikan kemudahan belajar kepada peserta didik secara adil dan merata, sehingga mereka dapat mengembangkan potensinya secara optimal

g. Memaksa Hak Anak Didik

- Melakukan pemaksaan kepada anak didik dan/atau orang tua anak anak didik untuk menuruti segala sesuai yang diinginkan/ditetapkan pendidik

\section{Pelaksanaan kegiatan main}

Kreatifitas sangat erat kaitanya dengan aktifitas peserta didik dan pendidik, pernyataan Jean Piaget $(1972 ; 27)$ tentang cara anak belajar sebagai berikut:

"Anak seharusnya mampu melakukan percobaan dan penelitian sendiri. Guru, tentu saja, bisa menuntun anak-anak dengan menyediakan bahan-bahan yang tepat, tetapi yang terpenting agar anak dapat memahami sesuatu, ia harus membangun pengertian itu sendiri, ia harus menemukannya sendiri”.

Peserta didik belajar melalui permainan, pengalaman bermain yang menyenangkan dengan bahan, benda, anak lain, menjadikan peserta didik 
pertumbuhan dan perkembangnya menjadi optimal baik fisik, emosi, kognisi, dan sosial. Lingkungan bermain harus bermutu tinggi mendukung tiga jenis bermain (Weikart, Rodgers, \& Adcock, 1971) dan teori dari Erik Erikson, Jean Piaget, Lev Vygotsky, dan Anna Freud: Sensorimotor atau main fungsional, Main peran (mikro dan makro) main pembangunan (sifat cair/bahan alam \& terstruktur).

1. Sensorimotor atau Main Fungsional. Piaget dan Smilansky (1968). Maksudnya adalah anak usia dini belajar melalui panca inderanya dan melalui hubungan fisik dengan lingkungan mereka.

2. Main Peran (Mikro dan Makro). Main peran disebut main simbolik, purapura, fantasi, imajinasi, atau main drama, main ini sangat penting untuk perkembangan kognisi, sosial, dan emosi anak pada usia tiga sampai enam tahun (Vygosky, 1967; Erikson, 1963). Main peran dipandang sebagai sebuah kekuatan yang menjadi dasar perkembangan daya cipta, tahapan ingatan, kerja sama kelompok, penyerapan kosa kata, konsep hubungan kekeluargaan, pengendalian diri, keterampilan pengambilan sudut pandang spasial, keterampilan pengambilan sudut pandang afeksi, keterampilan pengambilan sudut pandang kognisi. (Gowen, 1995).

3. Main Pembangunan. Main pembangunan Piaget (1962) dan Smilansky (1968). Piaget menjelaskan bahwa kesempatan main pembangunan membantu anak untuk mengembangkan keterampilannya yang akan mendukung keberhasilan sekolahnya dikemudian hari.

Kreatifitas pendidik dapat dilihat dari tugas dan fungsi dan posisinya diantaranya,

1. Supervisor,

Supervisi diberikan berupa bantuan (bukan perintah), sehingga inisiatif tetap berada di tangan peserta didik. Supervisi dilakukan dalam suasana terbuka, secara tatap muka, dan supervisor lebih banyak mendengarkan serta menjawab pertanyaan pesertadidik \& orang tua dari pada memberi saran/pengarahan. Supervisi dilakukan secara berkelanjutan utuk memecahkan permasalahan yang muncul dalam upaya meningkatkan kualitas peserta didik.

2. Inovator,

Pendidik memiliki strategi yang tepat untuk menjalin hubungan yang harmonis dengan lingkungan, mencari gagasan baru, mengintegra-sikan setiap kegiatan, memberikan teladan kepada seluruh peserta didik mengembangkan model-model pembelajaran yang inovatif. Pendidik 
sebagai inovator akan tercermin dari cara-cara melakukan pekerjaannya secara konstruktif, kreatif, intergratif dan pragmatis.

Konstruktif: berusaha mendorong dan membina setiap peserta didik agar dapat berkembang secara optimal. Kreatif, mencari gagasan dan caracara baru dalam melaksanakan tugasnya. Integratif, berusaha mengintegrasikan semua kegiatan sehingga dapat menghasilkan siinergi untuk mencapai tujuan secara efektif, efisien dan pruduktif. Pragmatis, berusaha menetapkan kegiatan atau target berdasarkan kondisi dan kemampuan nyata yang dimiliki oleh setiap peserta didik

\section{Motivator}

Sebagai motivator, pendidik harus memiliki strategi yang tepat untuk memberikan motivasi kepada para, peserta didik dalam melakukan berbagai kegiatan. Motivasi ini dapat ditumbuhkan melalui: pengaturan lingkungan fisik, suasana kerja, disiplin, dorongan, penghargaan secara efektif.

Pengaturan lingkungan fisik, Pendidik harus mampu membangkitkan motivasi peserta didik agar dapat brmain secara optimal. Pengaturan lingkungan fisik tersebut antara lain mencakup ruang belajar, tempat bermain serta sarana yang ada serta mengatur lingkungan yang aman dan menyenangkan.

Pengaturan suasana bermain, Pendidik harus mampu menciptakan hubungan sosial yang harmonis dengan peserta didik, serta menciptakan lingkungan yang aman dan menyenangkan.

Disiplin, Pendidik harus berusaha menanamkan disiplin kepada semua peserta didik. Melalui disiplin ini diharapkan dapat tercapai tujuan secara efektif dan efisien, serta dapat meningkatkan prumbuhan dan prkembangan anak.

Dorongan, Pendidik harus berusaha memberikan dorongan/motivasi kepada pesrta didik sehingga dapat meningkatkan permainan yang sedang dihadapi, mengeluarkan isi hati dan merealisasikan gagasan yang ada pada dirinya.

\section{Pemilihan Strategi Pembelajaran Kreatif}

1. Berpusat pada anak, artinya anak merupakan sasaran dalam kegiatan pembelajaran yang dilakukan oleh pendidik

2. Mendorong perkembangan fisik, daya pikir, daya cipta, emosional, bahasa dan komunikasi sebagai dasar pembentukan pribadi manusia yang utuh 
3. Memperhatikan perbedaan individu, baik perbedaan keadaan jasmani, rohani, kecerdasan dan tingkat perkembangannya (developmentally appropriate program)

4. Berpusat pada anak, artinya anak merupakan sasaran dalam kegiatan pembelajaran yang dilakukan oleh pendidik

5. Memperhatikan perbedaan individu, baik perbedaan keadaan jasmani, rohani, kecerdasan dan tingkat perkembangannya (developmentally appropriate program Berpusat pada anak, artinya anak merupakan sasaran dalam kegiatan pembelajaran yang dilakukan oleh pendidik

\section{E. Pelaksanaan Pembelajaran Kreatif}

Ketika melaksanakan proses bermain, anak merasa gembira dan senamg, pada saat itu untuk memberikan stimulasi dan motifasi sangat tepat dan pemberian motivasi selalu mengacu pada 9 kecerdasan atau kecerdasan jamak.

1. Kecerdasan linguistic yang dapat berkembang bila dirangsang melalui berbicara, mendengar, membaca, menulis, berdiskusi, dan bercerita.

2. Kecerdasan logika-matematika yang dapat dirangsang melalui kegiatan menghitung, membedakan bentuk, menganalisis data \& bermain dengan benda-benda.

3. Kecerdasan musical yang dapat dirangsang melalui irama, nada, birama, berbagai bunyi \& bertepuk tangan.

4. Kecerdasan kinestetik yang dapat dirangsang melalui gerakan, tarian, olahraga, \& gerakan tubuh.

5. Kecerdasan visual-spasial yaitu kemampuan dalam memahami ruang yang dapat dirangsang melalui bermain balok-balok dan bentuk-bentuk geometri melengkapi puzzle, menggambar, melukis, menonton film maupun bermain dengan daya khayal (imajinasi).

6. Kecerdasan interpersonal kemampuan untuk melakukan hubungan antar manusia (berkawan) yang dapat dirangsang melalui bermain bersama teman, bekerjasama, bermain peran, dan memecahkan masalah serta menyelesaikan konflik.

7. Kecerdasan intrapersonal kemampuan memahami diri sendiri yang dapat dirangsang melalui pengembangan konsep diri, harga diri, mengenal diri sendiri, percaya diri, kontrol diri dan disiplin.

8. Kecerdasan naturalis yaitu mencintai keindahan alam, yang dapat dirangsang melalui pengamatan lingkungan, bercocok tanam, termasuk mengamati fenomena alam.

9. Kecerdasan spiritual yaitu kemampuan mengenal dan mencintai ciptaan Tuhan, yang dirangsang melalui penanaman nilai-nilai moral dan agama. 


\section{F. Penutup}

Media pembelajaran dapat dimaknaisebagai alat komunikasi yang digunakan dalam proses pembelajaran untuk membawa informasi berupa materi ajar dari sumber belajar (guru/tutor) kepada warga belajar sehingga lebih tertarik untuk mengikuti pembelajaran. Dalam konteks pendidikan anak usia dini (PAUD) tentunya lebih selektif dalam memilih media pembelajaran. Dengan pendekatan bermain,anak menjadi lebih antusias dan guru dapat memanfaatkan untuk menyampaikan pesan-pesan pembelajaran sesuai tujuan yang hendak dicapai.

Permainan edukatif kreatif dapat bersumber dari lingkungan alam sekitar peserta didik, karena lingkungan merupakan media yang sangat tepat untuk dijadikan bahan pembelajaran bagi anak. Permainan tersebut berupa bahan mentah atau benda yang sudah siap pakai digunakan menjadi media permainan edukatif, maupun yang harus dibuat baru atau dimodifikasi /dilengkapi.

Permainan edukatif kreatif berfungsi sebagai sumber pengetahuan, keterampilan yang baru bagi anak, sekaligus sebagai medium pengembangan nalar dan kreatifitas anak, seperti berfikir, menganalisa, memecahkan masalah sendiri, serta berbuat secara sistematik dan logik.

\section{DAFTAR PUSTAKA}

Depdiknas. (2003). Alat Permainan Edukatif untuk Kelompok Bermain. Jakarta: Direktorat Padu Dirjen PNFI Depdiknas

Tedjasaputra, Mayke S. (2001). Bermain, Mainan, dan Permainan untuk Pendidikan Anak Usia Dini. Jakarta: Grasindo.

Depdiknas. (2004). Main Pembangunan, Seri Panduan Pelatihan Lebih Jauh Tentang Sen-tra Dan Saat Lingkaran. Jilid 4. Jakarta: Direktorat Padu Depdiknas.

Megawangi, R. (2006) Yang Terbaik Untuk Buah Hatiku. Bandung: Khansa' lini Pener-bitan MQS Publishing

Patmonodewo, S. (2003). Pendidikan Anak Prasekolah. Jakarta: Rineka Cipta. 